\title{
The Effect of E-WOM and Perceived Value on the Purchase Decision of Foods by Using the Go-Food Application as Mediated by Trust
}

\author{
DOI: 10.12776/QIP.V22I2.1062
}

Handi Handi, Tonny Hendratono, Edi Purwanto, John J.O.I. Ihalauw

Received: 20 March 2018

Accepted: 06 May 2018

Published: 31 July 2018

\begin{abstract}
Purpose: This study examined the effect of electronic word of mouth and perceived value on purchase decisions of foods when using the Go-Food Application, which is a purchase decision mediated by trust. The increasing the number of Go-Food Application users makes this study a timely survey.

Methodology/Approach: This research explored how the Go-Food Application is able to obtain more consumers compared to similar mobile apps. This research is quantitative in nature by testing the hypotheses. The sample size used was 175 respondents from a non-probability sampling with a convenience sampling technique. The analysis uses a SEM model analyzed using the AMOS program 24.

Findings: The results based on Confirmatory Factor Analysis (CFA) shows that each variable is valid and reliable, and the result of Goodness of Fit shows all variables fit the data. The result of hypotheses testing show: (1) electronic word of mouth affects significantly and positively on trust; (2) perceived value affects significantly and positively on trust; (3) electronic word of mouth affects significantly and positively on purchase decision; (4) perceived value affects significantly and positively on purchase decision; (5) trust affects significantly and positively on purchase decision.
\end{abstract}

Research Limitation/implication: The respondents were only those who live in Jakarta and those who use Go-Food application owned by Go-Jek Indonesia Ltd., exclude its other application such as Go-Car, Go-Mart, Go-Send, Go-Box, GoPulsa, Go-Massage, Go-Clean.

Originality/Value of paper: Trust proved as mediation variable between of electronic word of mouth and perceived value and purchase decision by using 
Go-Food application. So this research has distribution to Go-Jek Indonesia Ltd. to maintain the costumer trust to get sustainable competitive advantage.

Category: Research paper

Keywords: electronic word of mouth; perceived value; trust and purchase decision

\section{INTRODUCTION}

In this digital era the development of technology has a great impact on daily life for its users. Technology increasingly makes things easier for people in conducting their activities, including for businessman or enterpreneurs. Creating an innovative and creative thing in running a business will differentiated from its competitors. Creating a technology based business or online business has became a trend in this era and fulfills the increasing of people's diverse needs. The proliferation of online businesses in Indonesia is also caused by the country's s high number of internet users

Table 1 - The Data of Internet Users in Countries (KOMINFO, 2017)

\begin{tabular}{|l|l|c|c|c|c|c|}
\hline & \multicolumn{6}{|c|}{ Top 6 countries by Internet Users 2013-2017 (millions) } \\
\hline & & 2013 & 2014 & 2015 & 2016 & 2017 \\
\hline 1 & China & 620.7 & 643.6 & 669.8 & 700.1 & 736.2 \\
\hline 2 & United States & 246.0 & 252.9 & 259.3 & 264.9 & 269.7 \\
\hline 3 & India & 167.2 & 215.6 & 252.3 & 283.8 & 313.8 \\
\hline 4 & Brazil & 99.2 & 107.7 & 113.7 & 119.8 & 123.3 \\
\hline 5 & Japan & 100.0 & 102.1 & 103.6 & 104.5 & 105.0 \\
\hline 6 & Indonesia & 72.8 & 83.7 & 93.4 & 102.8 & 112.6 \\
\hline
\end{tabular}

Based on the data, Indonesian internet users have been increasing every year. One of the businesses that is enjoying extraordinary success is Go-Jek Indonesia Ltd., which provides an application that can be downloaded on $\mathrm{iOS}$ or android based smartphones. This application is called Go-Food from which people can order foods. The availability of restaurants in the application is about 30,000, and even more have become partners of the Go-Food application by providing many kinds of foods to choose from www.go-food.co.id. The following insight is based on the result of a survey conducted using a business perspective on how many Go-Food users exist and what are other similar mobile applications used for ordering foods.

Tab. 2 shows the survey was conducted on 400 respondents that use one or more food applications. Go-Food has $46 \%$ users, and compared to its competitior namely Grab Food, which is only has $1 \%$ users. This marked difference indicates 
that the Go-Food application is preferred by users. Further information from the survey shows that users who have more than one application on their mobile device are mostly Go-Food users. The result means that the users of the Go-Food application have reached more than $90 \%$ of the total number of respondents.

Table 2 - The Data of Foods Application Users(The Business Perspective, 2017)

\begin{tabular}{|l|c|}
\hline \multicolumn{1}{|c|}{ Foods Applications } & Users percentage \\
\hline Go-Food & $46 \%$ \\
\hline Grab Food & $1 \%$ \\
\hline Restaurants Apps & $3 \%$ \\
\hline$>1$ Applications & $50 \%$ \\
\hline
\end{tabular}

The study was preceded by identifying the following issues from other studies: (1) A research conducted by Baskara (2014) stated that trust does not affect significantly on purchase decisions, whereas Permatasari (2015) found that trust has a positive and significant effect on purchase decisions. This leads to the research question of customer trust towards the Go-Food application while deciding to order foods. (2) To create a positive electronic word of mouth (EWOM) promotion will be difficult if the services provided are not in-line with customer expectation. Thus, the question of how E-Wom can affect trust and purchase decision on Go-Food users is derived. In addition, (3) through perceived value, a customer can evaluate and judge the product or service before it is purchased. If the experience of ordering food through the Go-Food application is unfavorable, it will impact the perceived value, which becomes negative and will affect trust and subsequent purchase decisions.

Based on the above problem identification, the research problems are as follows: (1) Is purchase decision influenced by electronic word of mouth? (2) Is purchase decision influenced by perceived value? (3) Is purchase decision influenced by trust? (4) Is trust influenced by electronic word of mouth? (5) Is trust influenced by perceived value?

Subsequently, the objectives of this research are as follows: (1) To prove the effect of electronic word of mouth on purchase decisions. (2) To prove the effect of perceived value on purchase decisions. (3) To prove the effect of trust on purchase decisions. (4) To prove the effect of electronic word of mouth on trust. (5) To prove the effect of perceived value on trust.

\section{LITERATURE REVIEW}

According to Kotler and Keller (2016, pp. 198), at the evaluation stage, a consumer will choose one preferred thing among several brands and will also create an intention to purchase it. This means that people will decide if a product or service to be bought already exists among alternative options, enabling 
evaluation and the best choice in the end. Schiffman and Kanuk (2009, pp.112) assert that a purchase decision is the choice of two alternatives, which means when someone makes a purchase decision, the act is already to choose one of several options. Purchase decision involves how the process of decision making is done.

Previous studies show that one of factors that influences purchase decisions is electronic word of mouth. Electronic word of mouth is a positive or negative statement that is made by potential customers, actual customers, and previous customers regarding to the product or company. This information is available for people or institutions via the internet. The development of online media makes it easy to deliver information. Jalilvand and Samiei (2012) said that electronic word of mouth is an important online space for customers to give their opinions and is considered more effective rather than word of mouth because its scope and accessibility is broader.

A study conducted by Themba and Mualala (2013) reported that electronic word of mouth affects positively and significantly on purchase decision. This means that experience expressed through electronic word of mouth will affect purchase decisions. Chang, Lee and Huang (2016) also found that electronic word of mouth affects positively and significantly on purchase decision. Almana and Mirza (2013) reinforces the finding that electronic word of mouth affects positively and significantly on purchase decision. This is due to many consumers obtaining information about products online, especially comments and reviews by other consumers. Based on the findings above, this research purposes the first hypothesis:

\section{H1: Electronic word of mouth affects positively on purchase decision.}

Another factor that influences purchase decision making is perceived value. Before making a purchase decision, generally customers will evaluate the product or service that is offered. The evaluations include comparingprice, quality, and whether or the product fulfills the customer's needs. Mosavi and Ghaedi (2012) stated that perceived value is defined as customers perceive the sacrifice and expenditure given in accordance with benefits they expect. Kotler and Amstrong (2014, pp.35) suggested that perceived value is based on customer evaluation about a product or service that is offered and considers the benefits received and cost incurred. Therefore, it can be concluded that perceived value is a customer's assessment of a product or service before purchasing it.

Research conducted by Yee and San (2013) stated that perceived value affects significantly on purchase decisions. This means that when perceived value is good, a customer will have a greater purchase decision intent. Hoang, et al. (2016) found that perceived value affects positively and does not significantly impact on purchase decisions because consumers think that perceived value does not necessarily guarantee a product has good quality. Priansa (2016) argued that perceived value affects positively and significantly on purchase decisions. Based on the findings above, this research purposes the second hypothesis: 


\section{H2: Perceived value affects positively on purchase decision.}

Trust is also a factor that influences a purchase decision. Morgan and Hunt (1994) argued that trust arises as a result of the partner reability and integrity, which is demonstrated through various attitudes such as consistency, competence, fairness, responsibility, and caring. Kim, Ferrin and Rao (2008) showed that trust plays an important role in the e-commerce system, how trust is the first thought of a consumer before doing an online transaction. If customers do not trust e-commerce, they will not buy a product or service.

Research conducted by Anggraeni and Madiawati (2016) stated that trust affects significantly on purchase decisions because many customers already trusted a product such as Traveloka Apps. Chin, Wafa and Ooi (2009) revealed that trust affects positively on purchase decisions. However, Baskara (2014) asserted that trust affects positively but not significantly on purchase decision because lack of attention during the transaction makes consumers feel uncertain about doing a purchase. Based on the findings above, this research purposes a third hypothesis:

\section{H3: Trust affects positively on purchase decision.}

A study conducted by Al-Debei, Akroush and Ashouri (2015) found that electronic word of mouth affects positively and does not significantly impact on trust. This is due to lack of information obtained by customers; they feel doubt in terms of personal data security and the transaction. Furthermore, Abubakar, et al. (2017) found that electronic word of mouth affects positively ontrust. Xiaorong, et al. (2011) agreed that electronic word of mouth affects positively and significantly on trust because when information is received continuously, this consistency increases the level of a customer's trust. Based on the findings above, this research purposes the fourth hypothesis:

\section{H4: Electronic word of mouth affects positively on trust.}

Research conducted by Lai (2015) stated that perceived value also affects positively on trust. Widiartini and Yasa (2017) found that perceived value affects positively and significantly on a customer's trust. Chinomona, Okoumba and Pooe (2013) found that perceived value affects positively and significantly on customer's trust when deciding to purchase a gadget. Based on the findings above, this research purposes the fifth hypothesis:

\section{H5: Perceived value affects positively on trust.}




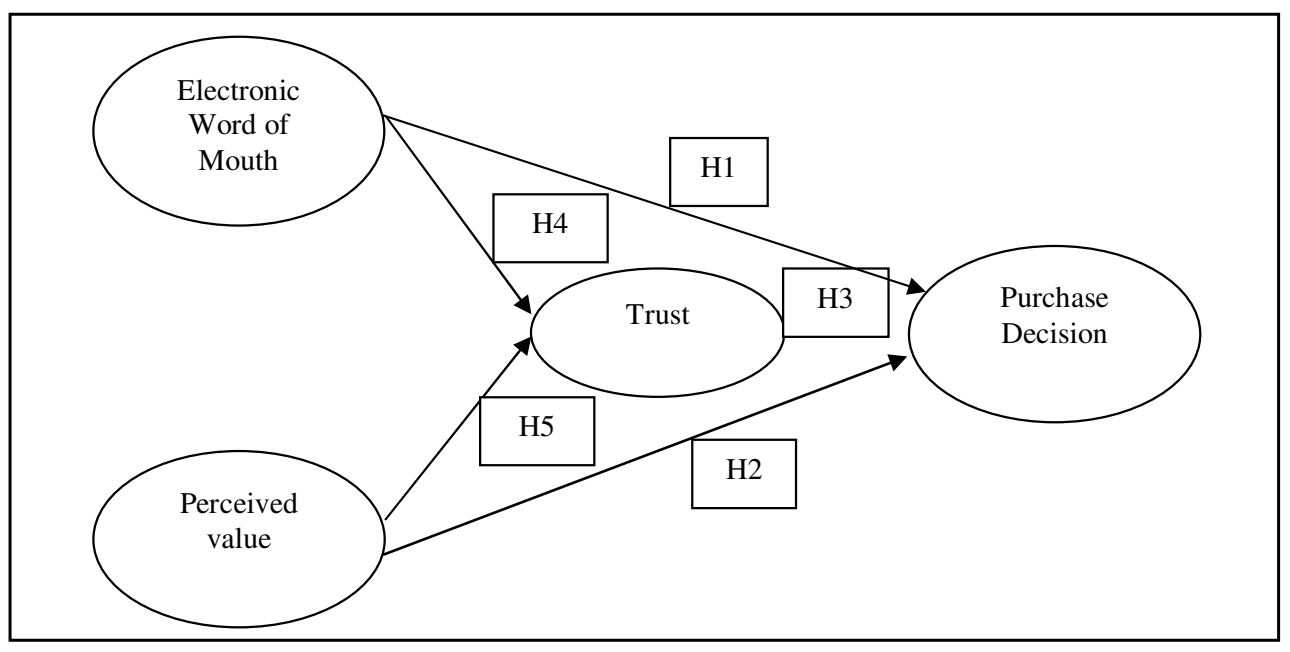

Figure 1 - Conceptual Framework

\section{METHODOLOGY}

According to Sekaran and Bougie (2013, pp. 240) population refers to an entire group of people, events, or things that attract a researcher to investigate it. The population for the current study is the users of the Go-Food Application in Jakarta. A Likert scale is more suitable to be used would this population because the Likert scale aims to measure attitudes, opinions, and perceptions of a person or group about a given social phenomena (Sugiyono, 2012, pp. 134) with a range from 1 to 5 .

This research used nonprobability sampling with a convenience sampling technique, in which, according to Solimun (2002) the size of the sample is about 5 to 10 times the number of manifest variables (indicator) from the entire latent variables (see also Karno and Purwanto, 2017; Jauw and Purwanto, 2017). The number of the whole indicator in this research is 24 , and minimal sample size be used in this research is $24 \times 7=168$ samples. In this research, the sample used is 175 respondents, which exceeds the recommended minimum.

According to Ghozali (2013, pp. 53), the validity test is used to measure whether or not a questionnaire is valid. A questionnaire is valid if the questions or statements are able to measure something that are in accordance with the questionnaire itself. Hair, et al. (2010) stated that an indicator is valid if it has a loading factor value $\geq 0.50$. A questionnaire is reliable if a respondent's answer is stable over time. In this research, an indicator of each variable is reliable if Variance Extracted (AVE) $\geq 0.50$ and Construct $(\mathrm{CR}) \geq 0.70$ Reliability (Ghozali, 2013, pp. 47-48).

The analysis technique is based on a Structural Equation Model (SEM) and analyzed using AMOS (Analysis of Movement Structure) software. SEM is a set of statistical techniques that testa set of relatively complex stimuli (Pardede and 
Manurung, 2015, pp. 60). There are three types of techniques according to Ferdinand (2002, pp. 70) as follows:

1. Confirmatory factor analysis on SEM is used to confirm the most dominant factors in variable groups. Confirmatory factor analysis is used to test indicators that create a purchase decision through Go-food Application.

2. Regression weights on SEM are used to examine how much variables can affect each other. Regression weights are used to test the hypotheses H1 to H5.

3. Evaluation criteria for Goodness of Fit have some indexes and a cut-off value to test whether a model can be accepted or not.

a. $\mathrm{X}^{2}$ Chi-square statistics, a model is good if has a lowchisquare value. The smaller the $\mathrm{X}^{2}$ value, the better the model is, and it can be accepted with a probabilily of $p>0.50$.

b. RMSEA (The Root Mean Square Error of Approximation) indicates the goodness of fit will be accepted if it has a small value or is equal to 0.08 . It shows a close fit model based on the degree of freedom.

c. GFI (Goodness Fit of Index) is a non-statistical measure that has a range between 0 (poor fit) to 1.0 (perfect fit). A high score indicates a better fit.

d. AGFI (Adjusted Goodness Fit of Index) is recommended to be equal or higher than 0.90 .

e. CMIN/DF (The Minimum Sample Discrepancy Function divided by Degree of Freedom) is an acceptable fit if it has an $\mathrm{X}^{2}$ valueless than 2.0 or 3.0 .

f. TLI (Tucker Lewis Index) is an incremental index that compares a tested model with a baseline model. A model will show a very good fit if the results of the test are more than 0.95 or close to 1.0.

g. CFI (Tucker Lewis Index) is recommended if the value his close to 1.0 or more than 0.95 .

\section{FINDINGS AND DISCUSSION}

All questionnaires were disseminated online, with 175 respondents who are considered to have appropriately completed the survey. Furthermore, respondents will be identified into several demographic categories for customer segments in order to better understand response characteristics. Respondents are grouped by gender. $65 \%$ were women and $35 \%$ were men. Based on age, there are of respondents $3 \%$ under 17 years old, $61 \%$ between 17 to 25 years old, $24 \%$ 
between 26 to 35 years old, $11 \%$ between 36 to 50 years old, and $1 \%$ over 50 years old. Education can be divided into $3 \%$ having completed junior high school, $46 \%$ senior high school, $11 \%$ having a diploma, $38 \%$ having earned a bachelor's degree, and $2 \%$ with a master's degree. Regarding occupation, $9 \%$ were house wives, $53 \%$ were private employees, $26 \%$ were students and $13 \%$ were self employed. Based on monthly income, $23 \%$ earn $1-5$ million, $38 \%$ earn 6-10 million, $10 \%$ earns above 10 million, and $28 \%$ have not earned an income yet.

Table 3 - Validity and Reliability Test

\begin{tabular}{|c|c|c|c|c|c|c|c|}
\hline No & Variable & Indicators & SLF & Validity & AVE & CR & Reliability \\
\hline \multirow[t]{5}{*}{1} & \multirow{5}{*}{$\begin{array}{l}\text { Electronic word } \\
\text { of mouth }\end{array}$} & EWOM1 & 0.660 & Valid & \multirow[t]{5}{*}{0.566} & \multirow[t]{5}{*}{0.766} & \multirow[t]{5}{*}{ Reliable } \\
\hline & & EWOM2 & 0.682 & Valid & & & \\
\hline & & EWOM3 & 0.624 & Valid & & & \\
\hline & & EWOM4 & 0.628 & Valid & & & \\
\hline & & EWOM5 & 0.547 & Valid & & & \\
\hline \multirow[t]{6}{*}{2} & \multirow[t]{6}{*}{ Perceived Value } & PV1 & 0.659 & Valid & \multirow[t]{6}{*}{0.666} & \multirow[t]{6}{*}{0.821} & \multirow[t]{6}{*}{ Reliable } \\
\hline & & PV2 & 0.625 & Valid & & & \\
\hline & & PV3 & 0.666 & Valid & & & \\
\hline & & PV4 & 0.619 & Valid & & & \\
\hline & & PV5 & 0.724 & Valid & & & \\
\hline & & PV6 & 0.653 & Valid & & & \\
\hline \multirow[t]{6}{*}{3} & \multirow[t]{6}{*}{ Trust } & $\mathrm{T} 1$ & 0.738 & Valid & \multirow[t]{6}{*}{0.672} & \multirow[t]{6}{*}{0.822} & \multirow[t]{6}{*}{ Reliable } \\
\hline & & $\mathrm{T} 2$ & 0.621 & Valid & & & \\
\hline & & $\mathrm{T} 3$ & 0.517 & Valid & & & \\
\hline & & $\mathrm{T} 4$ & 0.647 & Valid & & & \\
\hline & & T5 & 0.741 & Valid & & & \\
\hline & & T6 & 0.681 & Valid & & & \\
\hline \multirow[t]{7}{*}{4} & \multirow{7}{*}{$\begin{array}{l}\text { Purchase } \\
\text { Decision }\end{array}$} & PD1 & 0.763 & Valid & \multirow[t]{7}{*}{0.798} & \multirow[t]{7}{*}{0.883} & \multirow[t]{7}{*}{ Reliable } \\
\hline & & PD2 & 0.677 & Valid & & & \\
\hline & & PD3 & 0.699 & Valid & & & \\
\hline & & PD4 & 0.619 & Valid & & & \\
\hline & & PD5 & 0.742 & Valid & & & \\
\hline & & PD6 & 0.781 & Valid & & & \\
\hline & & PD7 & 0.754 & valid & & & \\
\hline
\end{tabular}


Regarding the first time knowing about the Go-Food application, 15\% knew about the application via the internet (website), $8 \%$ through family or relatives,35\% through social media (Facebook, Twitter, Instagram, Path, YouTube, Testimonial), and 42\% new about the Go-Food application through friends or relations.

Based on Tab. 3, all variables and indicators are shown to be valid and reliable because they met the criteria of standard loading factor ( $S L F \geq 0.50$ ), variance extracted (AVE $\geq 0.50)$, and construct reliability $(\mathrm{CR} \geq 0.50)$. Prior to hypothesis testing, the data needs to be tested using the Goodness of Fit test.

Tab.4 shows that all of the indexes in the Goodness of Fit test are fit or good. The chi square result is 259.594, which is smaller than the degree of freedom 263.147 with the level of significance set to $0.05(5 \%)$ which is good or fit. Other criteria such as Probability, RMSEA, GFI, AGFI, CMIN/DF, TLI, CFI are fit and results are also supported by the value of loading factor for each indicator being valid.

Table 4 - Goodness of Fit Index

\begin{tabular}{|l|r|r|r|}
\hline \multicolumn{1}{|c|}{ Goodness of Fit Index } & \multicolumn{1}{c|}{ Cut-off Value } & \multicolumn{1}{c|}{ Result } & Evaluation \\
\hline$X^{2}$ Chi-Square $(\mathrm{df}=227)$ & Expected small & 259.594 & Fit \\
\hline Probability & $\geq 0.05$ & 0.068 & Fit \\
\hline RMSEA & $\leq 0.08$ & 0.029 & Fit \\
\hline GFI & $\geq 0.90$ & 0.894 & Fit \\
\hline AGFI & $\geq 0.90$ & 0.860 & Marginal \\
\hline CMIN/DF & $\leq 2.00$ & 1.144 & Fit \\
\hline TLI & $\geq 0.95$ & 0.980 & Fit \\
\hline CFI & $\geq 0.95$ & 0.983 & Fit \\
\hline
\end{tabular}

The next analytic step is hypotheses testing to find out whether the hypotheses are accepted or not. The test itself will be looking at p-value on the output of regression weights. If the p-value is less than 0.05 , then the hypothesis is accepted and significant. The table of regression weights are shown in Tab.5.

Table 5 - Regression Weights

\begin{tabular}{|l|c|l|r|c|c|c|c|}
\hline & & & Estimate & S.E. & C.R. & P & Label \\
\hline Purchase Decision & $\leftarrow$ & E-WOM & .182 & .089 & 2.044 & .041 & par_13 \\
\hline Purchase Decision & $\leftarrow$ & Pervceived Value & .393 & .184 & 2.133 & .033 & par_14 \\
\hline Purchase Decision & $\leftarrow$ & Trust & .577 & .217 & 2.661 & .008 & par_24 \\
\hline Trust & $\leftarrow$ & E-WOM & .188 & .092 & 2.053 & .040 & par_25 \\
\hline Trust & $\leftarrow$ & Pervceived Value & .714 & .115 & 6.181 & $* * *$ & Par_26 \\
\hline
\end{tabular}


Hypothesis 1 (H1) states that electronic word of mouth has an effect on purchase decision. On Tab.5 shows that -value is 0.041 or under 0.050 , so the hypothesis is accepted. This means that electronic word of mouth affects the respondents to use Go-Food application. Hypothesis $2(\mathrm{H} 2)$ states that perceived value has an effect on purchase decision. Tab.5 shows that the p-value is 0.033 or under 0.050 , so the hypothesis is accepted, which means that perceived value of respondents affects them to make a purchase decision through the Go-Food application. Hypothesis 3 (H3) states that trust effects purchase decisions. Tab.5 shows that the p-value is 0.008 or under 0.050 , so the hypothesis is accepted. This means that the majority of respondents trust the Go-Food application and will make a purchase decision when using the application. Hypothesis 4 (H4) states that electronic word of mouth has an effect on trust. Tab.5 shows that the p-value is 0.040 or under 0.050 , so the hypothesis is accepted. This result means that electronic word of mouth affects a respondent's trust in using the Go-Food application. Hypothesis 5 (H5) states that perceived value impacts trust. Tab.5 shows that p-value is 0.000 or under 0.050 , so the hypothesis is accepted, meaning that perceived value of respondents affects their trustin using the GoFood application.

The study proves that the first hypothesis is accepted, which is that the electronic word of mouth has a direct positive effecton purchase decisions. This finding is supported Themba and Mulala (2013) whereby electronic word of mouth affects positively and significantly on purchase decision. The majority of respondents' ages are between 17-25 years old, and at that age the respondents are likely to have a sense of curiousity to prove something. If the information about Go-Food are interesting, then the user in this age bracket is likely toimmediately make a purchase. The average respondent income is 6 to 10 million IDR or about US $\$ 600$ to $\$ 1,000(39 \%)$, and it is possible to purchase through Go-Food application.

The study also proves that the second hypothesis is accepted, in which perceived value has direct positive effects on purchase decisions. This result is supported Yee and San (2013) who also found that perceived value affects significantly on purchase decisions. Regarding the respondent's profile who are dominated by young ages and good educational background, it is easy to find out any information through the internet and users can interact with others about the GoFood application. This leads them to form a sense of perceived value. Respondents have gained experiences after using the application and most of themagree with the perceived value statements and will form a purchase decision. In this research, perceived value affects positively on purchase decision, which means they think positively thus far about the Go-Food application.

The third hypothesis also is accepted. Trust has a direct positive effect on purchase decisions. This result is supported by Anggraeni and Madiawati (2016) who argued that trust affects significantly on purchase decisions. By looking the majority of respondents being 17-25 years old (61\%) and most recent education is senior high school (44\%), nonetheless students $(27 \%)$ are smart to formulate 
trust by feeling the services given. When the trust is established, the tendency to buy foods through the Go-Food application will be greater. Most of them also claim that they learned about the Go-Food application for the first time from friends or relations $(36 \%)$, which means they can find out more about the application by asking people they know directly. Therefore, the trust itself can increase the purchase transactions.

The fourth hypothesis is also accepted, demonstrating that electronic word of mouth has a direct positive effect on trust. This result is supported by the work of Xiaorong, et al. (2011) who that electronic word of mouth affects positively and significantly on respondent's trust. The respondents' profile shows that the majority of them are $17-25$ years old $(61 \%)$ and have a tendency to think critically, whereby they can analyze the truth of information through social media. This is also supported by good background education being senior high school (44\%) and recent technological advances will facilitate them to seek information through electronic media because it easier and faster than more traditional means of obtaining information from from others face-to-face. In this research, what has been read about the Go-Food application through social media will create a respondent's trust.

Finally, the fifth hypothesis also is accepted, in which perceived value has a direct positive effect on trust. This result is supported Widiartini and Yasa (2017) who stated that perceived valuehas apositiveand significant effect on trust. Through the respondent's profile, most of them have a good background education, which is senior high school (44\%) up to bachelor's degree $(40 \%)$, such that these respondents can evaluate information before developing trust in order to form a perceived value later. This perceived value is not limited by evaluation of quality band price, but also by how the respondents feel about the Go-Food application itself. They tend to do an assessment before finally being able to trust the application

\section{CONCLUSION}

The above summaries provide the conclusions for the current research. Firstly, purchase decision is affected by electronic word of mouth, which means electronic word of mouth is being read in social media and can encourage people to buy foods on the Go-Food application. Secondly, purchase decision is affected by perceived value, which means the better perceived value formed by Go-Food users, the higher the tendency to purchase foods through the application. When the services given are good, that will create a better perceived value because users can evaluate all services from the experiences, whether it already met their needs or not. Thirdly, purchase decision is affected by trust, which means if trust is increased, then the purchase decision will be increased as well. Creating the customer's trust is not easy but Go-Jek needs to improve service quality especially in the Go-Food apps. Fourthly, trust is affected by electronic word of mouth, which means through reading the reviews or Go-Food's users' 
experiences in social media impact someone's trust towards the information. Fifthly, trust is affected by perceived value, which means if perceived value increases, then the user's trust will increase as well. After purchasing foods through the Go-Food applicaton, users can evaluate the services that they experienced. Through perceived value, users can evaluate the Go-Food application in terms of price, quality, and what they feel after having used it. Sixthly, this result indicates that electronic word of mouth affects positively and significantly on purchase decision if mediated by trust and that perceived value affects positively and significantly on purchase decisions if mediated by trust.

\section{SUGGESTIONS AND LIMITATIONS}

The suggestions of the research are: (1) the variable of electronic word of mouth has the lowest value compare to other variables based on the respondents' answers. Nonetheless, it is difficult for Go-Jek Indonesia Ltd. to direct its users to write good reviews on social media because it depends on what they feel about the Go-Food application. However, as long as the information and services are well provided, it is possible to create positive electronic word of mouth. Other important factors, such as information about price, food choices, and security in the Go-Food application should be appropriate to reality because any discrepancy between what is promised and what is experienced will decrease the level of user trust and their subsequent purchase decisions. (2) Perceived value itself is considered good by Go-Food users, and can be seen on in their average answer about the safety, food choices, and enjoyment in using this app. This result needs to be defended by Go-Jek and be improved to add more food items to the menu to increase interest in purchasing foods through the Go-Food application. (3) the existence of promotions by Go-Jek such giving a discount on particular foods will attract other users to engage in purchasing behavior. According to this research, the information about promos is mostly read by the respondents through social media, which is a practice that should be maintained. Moreover, the advantage of using promos will increase the user' $s$ trust, perceived value, and results with a purchase decision. All the suggestions above need to be maintained in order to keep this application improving in the future.

The limitations of the research are: (1) this research proves that there are positive and significant affects between variables, weather dependent (trust and purchase decision) or independent (electronic word of mouth and perceived value). Further research can expand the indicators or add other variables that can affect purchase decisions such as service quality, word of mouth, or customer loyalty. (2) This research is limited to the Go-Food application owned by Go-Jek Indonesia Ltd. Future research can change the objects of research besides Go-Food, such as GoCar, Go-Mart, Go-Send, Go-Box, Go-Pulsa, Go-Massage, Go-Clean, or any transportation objects beyond Go-Jek's ownership. (3) The sample area of respondents is only those who live in Jakarta. Thus, additional research can take a wider respondent area and include other cities in Indonesia. Go-Jek itself is 
already spread across several cities, which will provide interesting insight to whether respondents' answers are consistent with the findings of this research.

\section{REFERENCES}

Abubakar, A.M., Ilkan, M., Al-Tal, R.M. and Eluwole, K.K.,2017. eWOM, revisit intention, destination trust and gender. Journal of Hospitality and Tourism Management, [e-journal] 31, pp.220-227. https://doi.org/10.1016/j.jhtm.2016.12.005.

Al-Debei, M.M., Akroush, M.N. and Ashouri, M.I. 2015. Consumer attitudes towards online shopping: The effects of trust, perceived benefits, and perceived web quality. Internet Research, [e-journal] 25(5), pp.707-733. https://doi.org/10.1108/IntR-05-2014-0146.

Almana, A.M. and Mirza, A.A., 2013. The Impact of electronic word of mouth on consumer's purchasing decisions. International Journal of Computer Applications, 82(9), pp.23-31.

Anggraeni, P. and Madiawati, P.N., 2016. Pengaruh kepercayaan dan kualitas informasi terhadap keputusan pembelian secara online pada situs www.traveloka.com. e-Proceeding of Management, 3(2), pp.1880-1887.

Baskara, I.P., 2014. Analisis pengaruh kepercayaan, keamanan, kualitas pelayanan dan persepsi akan resiko terhadap keputusan pembelian melalui situs jejaring sosial. Final Project. Semarang: Universitas Dian Nuswantoro Semarang.

Chang, L.Y., Lee, Y.J. and Huang, C.L., 2016. The influence of e-word-of-mouth on the consumer's purchase decision: a case of body care products. The Journal of Global Business Management, [e-journal] Available through: The Journal of Global Business

Management $<$ http://www.jgbm.org/page/2\%20Yu_je\%20Lee.pdf> [Accessed 15 June 2017].

Chin, A.J., Wafa, S.A.W.S.K. and Ooi, A.Y., 2009. The effect of internet trust and social influence towards willingness to purchase online in Labuan, Malaysia.International Business Research, [e-journal] 2(2), pp.72-81. http://dx.doi.org/10.5539/ibr.v2n2p72.

Chinomona, R., Okoumba, L. and Pooe, D., 2013. The impact of product quality on perceived value, trust and students' intention to purchase electronic gadgets. Mediterranean Journal of Social Sciences, 4(4), pp.463-472.

Ferdinand, A., 2002. Structural equation modeling dalam penelitian manajemen. Semarang: Badan Penerbit Universitas Diponegoro.

Ghozali, I., 2013. Aplikasi analisis multivariate dengan program IBM SPSS 21. Semarang: Badan Penerbit Universitas Diponogoro. 
Hair, J.F., Black, W.C., Babin, B.J. and Anderson, R.E., 2010. Multivariate data analysis: A global perspective. New Jersey: Pearson Education, Inc.

Hoang, T.P., Tuan, N.M., Khanh, V.H. and Duc, L.M., 2016. The impact of perceived value to the purchasing decisions of consumers for natural cosmetic products: A study on "M White" natural cosmetic brands of D.O PRO Joint Stock Company in Vietnam. American Based Research Journal, 5(12), pp.25-33.

Jalilvand, M.R. and Samiei, N., 2012. The effect of electronic word of mouth on brand image and purchase intention: An empirical study in the automobile industry in Iran. Marketing Intelligence \& Planning, 30(4), pp.460-476.

Jauw, A.L.J. and Purwanto, E., 2017. Moderation effects of cultural dimensions on the relationship between e-service quality and satisfaction with onlinepurchase. Quality - Access to Success, 18(157), pp.55-60.

Karno, C.G. and Purwanto, E., 2017. The effect of cooperation and innovation on business performance. Quality - Access to Success, 18(158), pp.123-126.

Kim, D.J., Ferrin, D.L. and Rao, H.R., 2008. A trust-based consumer decisionmaking model in electronic commerce: The role of trust, perceived risk, and their antecedents. Decision support system, 44(2), pp.544-564.

KOMINFO, 2017. Kementerian Komunikasi dan Informatika Republic Indonesia. [online] Available at: <https://www.kominfo.go.id/> [Accessed 15 June 2017].

Kotler, P. and Amstrong, G.,2014. Principle of marketing. 15 ed. Upper Saddle River, NJ, US: Pearson Prentice Hall, Inc.

Kotler, P. and Keller, K.L., 2016. Marketing management. 15 ed. Upper Saddle River, NJ, US: Pearson Education, Inc.

Lai, Y.H., 2015. Enhance online purchase intentions: The role of rerceived value, trust, and commitment. Journal of Tourism and Hospitality Management, 3(2), pp.89-99.

Morgan, R.M. and Hunt, S.D. 1994. The commitment-trust theory of relationship marketing. Journal of Marketing, 58(3), pp.20-38.

Mosavi, S.A. and Ghaedi, M., 2012. An examination of the effects of perceived value and attitude on consumers behavioral intentions in e-shopping. African Journal of Business Management, 6(5), pp.1950-1959.

Pardede, R. and Manurung, R., 2015. Prosedur dan aplikasi AMOS dalam penelitian model persamaan struktural. Jakarta: Penerbit Harfamedia.

Permatasari, C.D.W., 2015. Pengaruh kepercayaan, keamanan, persepsi resiko, dan kualitas pelayanan terhadap keputusan pembelian secara online (Studi pada pengguna situs olx.co.id d/h berniaga.com). Final Project. Semarang: Universitas Dian Nuswantoro Semarang. 
Priansa, D.J., 2016. Pengaruh e-wom dan persepsi nilai terhadap keputusan konsumen untuk berbelanja online di Lazada. Journal of Ecodemica, 4(1), pp.117-124.

Schiffman, L.G. and Kanuk, L.L., 2009. Consumer behavior. Upper Saddle River, NJ, US: Prentice Hall, International.

Sekaran, U. and Bougie, R., 2013. Research methods for business. United Kingdom: John Wiley \& Sons Ltd.

Solimun, 2002. Structural equation modeling, Lisreldan Amos. Malang: Fakultas MIPA, Universitas Brawijaya.

Sugiyono, 2012. Metode penelitian kuantitatif kualitatif dan R\&D. Bandung: Alfabeta.

The Business Perspective, 2017. The business perspective oleh Fakhrurroji Hasan. [online] Available at: $<$ https://thebusinessperspectiveblog.wordpress.com/> [Accessed 15 June 2017].

Themba, G. and Mulala, M., 2013. Brand-related e-wom and its effects on purchase decisions: An empirical study of University of Botswana students. International Journal of Business and Management, 8(8), pp.31-40.

Widiartini, P.R. and Yasa, N.N.K., 2017. Peran kepercayaan dalam memediasi hubungan persepsi nilai dengan niat menggunakan e-money. Matrik: Jurnal Manajemen, Strategi Bisnis dan Kewirausahaan, 11(1), pp.11-25.

Xiaorong, F., Bin, Z., Qinghong, X., Liuli, X. and Yu, C., 2011. Impact of quantity and timeliness of e-wom information on consumer's online purchase intention under $\mathrm{C} 2 \mathrm{C}$ environment. Asian Journal of Business Research, 1(2), pp.37-52.

Yee, C.J. and San, N.C., 2013. Consumer's perceived quality, perceived value and perceived risk towards purchase decision on automobile. American Journal of Economics and Business Administration, 3(1), pp.47-57. 


\section{ABOUT AUTHORS}

Handi Handi - graduate at the the Graduate School of Management, Bunda Mulia University, Jakarta, Indonesia, email: handiangg@gmail.com.

Dr. Tonny Hendratono - Senior Lecturer at the Graduate School of Management and Vice Rector for Student Affairs of Bunda Mulia University, Jakarta, Indonesia, email: tony@bundamulia.ac.id.

Dr. Edi Purwanto - Senior Lecturer at the Department of Management, Bunda Mulia University, Jakarta, Indonesia, email: epurwanto@bundamulia.ac.id.

John J.O.I. Ihalauw, PhD. - Professor and Senior Adviser of Bunda Mulia University, Jakarta, Indonesia, email: ihalauw@bundamulia.ac.id.

(C) 2018 by the authors. Submitted for possible open access publication under the terms and conditions of the Creative Commons Attribution (CC-BY) license (http://creativecommons.org/licenses/by/4.0/). 